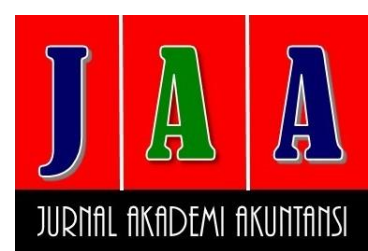

Website:

ejournal.umm.ac.id/index.php/jaa

Afiliasi:

${ }^{1}$ Fakultas Ekonomi dan Bisnis, Universitas Brawijaya, Malang, Indonesia

*Correspondence:

achmad.zwageri@gmail.com

DOI: $10.22219 /$ jaa.v3i2.11987

Sitasi:

Zwageri, A. (2020). Pengaruh Karakteristik Tim Manajemen Puncak Terhadap Manajemen Laba Dengan Kualitas Audit Sebagai

Variabel Pemoderasi. Jurnal Akademi Akuntansi, 3(2), 133-152.

Proses Artikel

Diajukan:

29 April 2020

Direviu:

2 Mei 2020

Direvisi:

13 Juli 2020

Diterima:

14 Juli 2020

Diterbitkan:

30 November 2020

Alamat Kantor:

Jurusan Akuntansi Universitas

Muhammadiyah Malang

Gedung Kuliah Bersama 2

Lantai 3.

Jalan Raya Tlogomas 246,

Malang, Jawa Timur,

Indonesia

P-ISSN: 2715-1964

E-ISSN: 2654-8321
Tipe Artikel: Paper Penelitian

\section{PENGARUH KARAKTERISTIK TIM MANAJEMEN PUNCAK TERHADAP MANAJEMEN LABA DENGAN KUALITAS AUDIT SEBAGAI VARIABEL PEMODERASI \\ Achmad Zwageri $^{i^{*}}$}

\section{ABSTRACT}

The purpose of this study is to analyze; the influence of the characteristics of the top management team on earnings management with audit quality as a moderating variable. The research sample was selected using the purposive method of manufacturing companies listed on the Indonesia Stock Exchange in the period 2014 - 2018. The research method used was hypothesis testing, and the model of this research analysis used a moderation regression analysis (MRA). The results of this study contribute to the upper echelon theory and show that top management characteristics that are proxied by knowledge and years of service have a negative influence on earnings management, and on audit quality as a moderating factor that is not proven to strengthen its effect on earnings management.

KEYWORDS: Audit Quality; Characteristics Of The Top Management Team; Earning Management; Upper Echelon Theory.

\section{ABSTRAK}

Tujuan dari penelitian ini adalah untuk menganalisis pengaruh karakteristik tim manajemen puncak terhadap manajemen laba dengan kualitas audit sebagai variabel moderasi. Sampel penelitian dipilih dengan menggunakan metode purposive pada perusahaan manufaktur yang terdaftar di Bursa Efek Indonesia periode 2014 2018. Metode penelitian yang digunakan adalah pengujian hipotesis, dan model analisis penelitian ini menggunakan analisis regresi moderasi (MRA). Hasil penelitian ini berkontribusi pada the upper echelon theory dan menunjukkan bahwa karakteristik manajemen puncak yang diproksikan dengan pengetahuan dan masa kerja berpengaruh negatif terhadap manajemen laba, dan kualitas audit sebagai faktor pemoderasi yang tidak terbukti memperkuat pengaruhnya. tentang manajemen laba.

KATA KUNCI: Karakteristik Tim Manajemen Puncak; Kualitas Audit; Manajemen Laba; Upper Echelon Theory. 


\section{PENDAHULUAN}

Laporan keuangan merupakan sarana pengkomunikasian informasi keuangan kepada pihakpihak di luar korporasi. Di dalam Statement of Financial Accounting Concept (SFAC) Nomor 1, dikatakan bahwa laporan keuangan harus dapat menyajikan informasi yang berguna untuk investor, calon investor, kreditur, dan kreditur potensial dalam mengambil keputusan investasi, kredit, dan keputusan lain yang sejenis, secara rasional. Informasi yang terkandung dalam laporan keuangan harus dapat dipahami oleh mereka yang memiliki wawasan bisnis dan ekonomi agar informasi yang disajikan dalam laporan keuangan cepat dipahami oleh semua pihak yang berkepentingan dan dapat digunakan untuk pengambilan keputusan, maka penyajian laporan keuangan dalam laporan tahunan harus disertai pengungkapan penuh, artinya memberikan informasi secara lengkap dan terbuka sehingga tidak menyesatkan orang yang membacanya.

Pada penyusunan laporan keuangan, dasar akrual dipilih karena rasional dan adil dalam mencerminkan kondisi perusahaan secara riil. Akuntansi berbasis akrual mempunyai keunggulan bahwa informasi laba perusahaan dan pengukuran komponennya berdasarkan akuntansi akrual secara umum memberikan indikasi lebih baik tentang kinerja ekonomi perusahaan daripada informasi yang dihasilkan dari aspek penerimaan dan pengeluaran kas terkini (FASB , 1978). Namun, akuntansi akrual juga memiliki kelemahan. Penggunaan dasar akrual dapat memberikan keleluasaan pada pihak manajemen dalam memilih metoda akuntansi dengan tujuan-tujuan tertentu yang bahkan dapat merugikan banyak pihak. Tindakan manajer yang dapat mempengaruhi angka laba dengan tujuan tertentu dikenal dengan istilah manajemen laba (earnings management) (Scott, 2015).

Praktik manajemen laba bukan merupakan istilah yang asing lagi di dunia bisnis internasional. Beberapa skandal besar telah membuat praktik manajemen laba menjadi perhatian serius oleh berbagai kalangan, seperti skandal Waste Management Houston pada tahun 1998 (Dowd, 2016), skandal Enron Corporation pada tahun (Li, 2010), skandal WorldCom pada tahun 2002 (Sidak, 2003), dan masih banyak skandal-skandal besar lain yang menarik perhatian dunia. Tidak hanya di dunia internasional kasus-kasus seperti ini terjadi, di Indonesia juga terdapat beberapa kasus-kasus manipulasi pendapatan yang sangat merugikan banyak pihak.

Pada teori akutansi positif (Positive Accounting Theory-PAT) Watts dan Zimmerman (1990) menjelaskan tiga hipotesis mengenai manajer melakukan manajemen laba, yaitu: the bonus plan hypothesis, the debt covenant hypothesis, dan political cost bypothesis. Hampir sejalan dengan teori akutansi positif (Watts dan Zimmerman, 1990), Scott (2015) mengemukakan terdapat empat motivasi manajer melakukan manajemen laba, yaitu; motivasi untuk mencapai tujuan bonus (bonus purposes), motivasi kontrak lainnya (other contracting motivations), motivasi untuk mencapai ekspektasi laba investor (to meet investors' earning expectations), dan penawaran saham (Stock offerings). Motivasi-motivasi inilah yang mendorong dan memberikan insentif besar bagi manajer untuk melakukan praktik manajemen laba.

Banyak hal yang seharusnya dapat membatasi praktik manajemen laba yang dilakukan oleh manajer. Salah satunya yang seharusnya paling berperan adalah Top Management Team (selanjutnya, tim manajemen puncak), karena tim manajemen puncak merupakan komponen penting perusahaan yang dapat mempengaruhi proses perencanaan strategis perusahaan $(\mathrm{Li}, 2014)$ dan tim manajemen puncak juga dapat menyelesaikan masalahmasalah penting mengenai organisasi sehingga mempengaruhi hasil organisasi (Huovinen dan Pasanen, 2010). Oleh karena itu, tim manajemen puncak tampaknya memiliki dampak yang signifikan terhadap strategi pelaporan keuangan perusahaan dan tingkat manajemen 
laba perusahaan. Hal ini juga sesuai dengan Upper Echelon Theory (Hambrick dan Mason, 1984).

Upper Echelon Theory Hambrick dan Mason (1984) menyatakan bahwa keputusan yang diambil organisasi seperti keputusan strategis dan implementasi strategi ditentukan oleh orang-orang besar yang memiliki peran penting dalam organisasi, yaitu para manajemen puncak. Teori ini dapat menjadi pijakan yang menarik dalam penelitian-penelitian dalam bidang kepempinan strategis (Johan dan Wibowo, 2012). Berdasarkan pada Upper Echelon Theory ini peneliti beranggapan bahwa karakteristik dari tim manajemen puncak menjadi faktor penting yang akan mempengaruhi keputusan strategis perusahaan terutama dalam keputusan penyusunan laporan keuangan dan manajemen laba. Karakteristik tim manajemen puncak yang menjadi fokus pada penelitian ini mengikuti penelitian sebelumnya oleh (Hsieh et al., 2018) yaitu pengetahuan tim manajemen puncak dan masa jabatan ratarata tim manajemen pucak.

Selain dasar teoritis tersebut, beberapa hasil penelitian empiris juga menunjukan bahwa tim manajemen puncak dapat mempengaruhi keputusan strategis perusahaan. Namun, studi yang secara khusus menyelidiki karakteristik tim manajemen puncak masih sangat terbatas. Arah pengaruh karakteristik tim manajemen puncak terhadap keputusan perusahaan juga masih menjadi perdebatan dikalangan akademisi. Terdapat dua perspektif yang berkembang mengenai karakteristik tim manajemen puncak yaitu perpektif incentive-reduction effect dan perspektif entrenchment-enhancing effect. Perspektif incentive-reduction effect manajemen yang memiliki pengetahuan yang lebih tinggi atau masa kerja yang lebih lama akan menghasilkan kinerja perusahaan yang lebih baik (Chemmanur dan Paeglis, 2005). Maka manajemen dengan tingkat pengetahuan yang lebih tinggi dan masa jabatan yang lebih lama akan berdampak positif terhadap perusahaan dan diharapkan dapat menghambat praktik manajemen laba.

Penelitian sebelumnya yang mendukung perspektif Incentive-reduction effect diantaranya temukan oleh (Xiong, 2016) yang melakukan penelitian mengenai pengaruh karakteristik petinggi perusahaan terhadap manajemen laba pada perusahaan-perusahaan China di Shenzhen dan Shanghai Stock Exchange tahun 2005 sampai dengan tahun 2014. Hasil penelitian ini menemukan bahwa masa jabatan petinggi perusahaan, umur petinggi perusahaan, dan Pendidikan petinggi perusahaan dapat membatasi praktik manajemen laba di perusahaan China.

Qi et al. (2018) meneliti dampak karakteristik tim manajemen puncak termasuk CEO dan CFO serta anggota tim lainnya terhadap pilihan strategi manajemen laba pada perusahan publik China yang listing pada tahun 2000 sampai dengan tahun 2015. Hasil penelitian ini menemukan bahwa usia, jumlah anggota tim perempuan, tingkat pendidikan, pengalaman kerja dibidang keuangan dapat membatasi praktik manajemen laba berbasis akrual dan manajemen laba riil.

Di Indonesia penelitian dilakukan oleh Annisa (2013) yang meneliti tentang latar belakang Pendidikan dewan komisaris, kepemilikan institusional dan ukuran perusahaan terhadap integritas laporan keuangan pada perusahaan-perusahaan manufaktur yang terdaftar di Bursa Efek Indonesia pada tahun 2008 sampai tahun 2010. Hasil penelitian ini menemukan

JAA bahwa latar belakang Pendidikan dewan komisaris berpengaruh positif terhadap integritas laporan keuangan perusahaan. Semakin tinggi latar belakang Pendidikan yang dimiliki oleh 3.2 dewan komisaris akan mendorong perusahaan untuk menyusun laporan keuangan yang dapat dipercaya oleh para penggunanya. 
Perspektif lainnya yaitu entrenchment-enhancing effect beranggapan bahwa pengetahuan dan masa jabatan yang lebih lama dapat memberikan kekuatan yang lebih besar atas strategi operasi perusahaan, sehingga akan dapat mendorong untuk terlibat dalam manajemen laba (Finkelstein, 1992). Perspektif ini didukung oleh Chou dan Chan (2018) yang meneliti pengaruh karakteristik CEO pada manajemen laba riil pada industri perbankan di Amerika Serikat pada tahun 2004 sampai 2007. Hasil penelitian ini menemukan bahwa pengalaman CEO justru dapat berdampak pada peningkatan praktik manajemen laba pada industri perbankan AS.

Temuan penelitian di atas dan adanya dua perspektif di atas menunjukan bahwa karakteristik manajemen puncak perusahaan memiliki peran penting dalam pembuatan keputusan perusahaan, namun arah pengaruhnya masih berbeda-beda. Dampak positif dan negatif masih ditemukan oleh para peneliti-peneliti sebelumnya. Maka dari itu, peneliti beranggapan bahwa perlu adanya pihak independen yang dijadikan sebagai mekanisme pengawasan yang efektif untuk mengawasi perilaku manajemen, karena tim manajemen puncak merupakan mekanisme internal perusahaan. Mekanisme pengawasan dapat mengatasi adanya konflik yang ada didalam perusahaan (Herawaty, 2008). Teori Agensi juga juga menyatakan bahwa mekanisme pengawasan dapat meredakan konflik kepentingan dan perilaku oportunistik (Alzoubi, 2016). Salah satu mekanisme pengawasan yang diusulkan dalam teori agensi yaitu audit independen.

Penelitian ini menggunakan kualitas dari audit independen sebagai mekanisme pengawasan yang diharapkan dapat memperkuat pengaruh dari karakteristik tim manajemen puncak khususnya pengetahuan dan masa jabatan rata-rata terhadap manajemen laba. Kualitas audit pada penelitian ini diukur dengan ukuran Kantor Akuntan Publik (KAP Big-4) mengikuti penelitian-penelitian sebelumnya (DeAngelo, 1981), (Challen dan Siregar, 2012), dan (Khanh dan Khuong, 2018). Ukuran KAP yang lebih besar memiliki sumber daya keuangan dan sumber daya manusia yang lebih baik, teknologi yang lebih canggih dibandingkan dengan KAP yang berukuran kecil, sehingga diharapkan dapat memberikan pemantauan yang lebih baik terhadap perusahaan.

Secara empiris, Rusmin (2010) melakukan penelitian mengenai pengaruh kualitas audit terhadap manajemen laba pada perusahaan-perusahaan berbadan hukum Singapura yang tercatat di SGX pada tahun 2003. Hasil penelitiannya menemukan bahwa perusahaan yang diaudit oleh auditor spesialis industri terlibat dalam manajemen laba yang lebih rendah daripada perusahaan yang diaudit oleh auditor non-spesialis. Selain itu, penelitian ini juga menemukan bahwa manajemen laba lebih rendah pada perusahaan yang diaudit oleh KAP big-4 dibandingkan dengan perusahaan yang diaudit oleh KAP nonbig-4. Pada penelitian ini peneliti tertarik melakukan penelitian terhadap teori upper echelon karena sedikitnya penelitian tentang latar belakang dari manajemen puncak yang akan mempengaruhi kualitas dari laporan akutansi perusahaan dan peneliti juga menggunakan kualitas audit sebagai variabel pemoderasi pada pengaruh karakteristik tim manajemen puncak terhadap manajemen laba. Diharapkan bahwa adanya audit yang berkualitas tinggi dapat semakin memperkuat kepemimpinan baik para manajemen puncak yang memiliki pengetahuan lebih tinggi dan masa jabatan lama di perusahaan.

\section{TINJAUAN PUSTAKA}

\section{Pengetahuan Manajemen Puncak dan Manajemen Laba}

Chemmanur dan Paeglis (2005) dalam penelitiannya menunjukkan bahwa karakteristik tim manajemen puncak yang memiliki kualitas yang baik dan lebih memiliki reputasi mampu menyampaikan nilai intrinsik perusahaan mereka lebih kredibel kepada orang luar, sehingga 
mengurangi asimetri informasi yang dihadapi perusahaan mereka di pasar ekuitas. Sehingga hal ini meningkatkan kinerja perusahaan dan mengurangi insentif manajer untuk memanipulasi laba. Demerjian et al. (2013) dalam penelitiannya menunjukan bahwa manajer yang baik mampu melaporkan laba berkualitas tinggi. Manajer yang memiliki pengetahuan yang lebih besar tentang bisnis perusahaan mereka, menunjukkan bahwa mereka dapat memperkirakan laba lebih akurat. Akibatnya, mereka cenderung tidak melakukan manajemen laba secara oportunistik. Argumen serupa, seperti Ali dan Zhang (2015) menunjukkan bahwa manajer sangat peduli dengan persepsi pasar tentang kemampuan mereka, karena dikaitkan dengan beberapa manfaat jangka panjang seperti kompensasi masa depan yang lebih tinggi, pengangkatan kembali, dan otonomi manajerial. Mengingat bahwa pasar akan mempertimbangkan laba yang dilaporkan serta reputasi tim manajemen puncak ketika menilai kemampuan manajer, tim manajemen puncak yang memiliki reputasi diharapkan menghadapi lebih sedikit tekanan untuk meningkatkan pendapatan untuk memengaruhi persepsi pasar karena pasar telah mengakui reputasi mereka. Sehingga, tim manajemen puncak dengan lebih banyak pengetahuan diharapkan lebih memiliki reputasi, yang mengurangi insentif manajer untuk mengelola pendapatan. Selanjutnya, manajer dengan lebih banyak keahlian diharapkan lebih megerti tentang standar pelaporan keuangan. Oleh karena itu, mereka lebih sadar akan biaya hukum potensial dari manajemen laba dan karenanya lebih kecil kemungkinannya untuk memanipulasi laba. Mengingat bahwa strategi pelaporan keuangan secara bersama-sama ditentukan oleh seluruh tim manajemen, perusahaan dengan tim manajemen puncak yang memiliki pengetahuan lebih besar mungkin lebih kecil kemungkinannya untuk mendapatkan persetujuan bersama untuk melakukan manajemen laba oportunistik. Berdasarkan penelitian-penelitian terdahulu maka hipotesis penelitian ini dinyatakan sebagai berikut;

\section{H1a: Pengetahuan Manajemen Puncak berpengaruh negatif terhadap manajemen laba akrual.}

\section{H1b: Pengetahuan Manajemen Puncak berpengaruh negatif terhadap manajemen laba riil.}

\section{Masa Jabatan Rata-rata Manajemen Puncak dan Manajemen Laba}

Tim manajemen puncak yang memiliki masa jabatan yang lama dapat dengan mudah berbagi pengalaman mereka dan mengurangi biaya transaksi dan asimetri informasi internal di antara anggota tim. Sehingga, tim manajemen puncak dengan masa kerja lebih lama memiliki kinerja operasi yang lebih tinggi (Haleblian dan Finkelstein, 1993) (Hambrick dan D'Aveni, 1992) (Michel dan Hambrick, 1992). Selain itu, (Chemmanur et al., 2009) menunjukkan bahwa tim manajemen puncak dengan masa kerja rata-rata yang lebih lama memiliki kebijakan keuangan dan investasi yang lebih baik dan mengarah pada kinerja yang lebih baik. Perusahaan dengan kinerja yang lebih baik memiliki tingkat manajemen laba yang lebih rendah (Aier et al., 2005) (Matsunaga dan Yeung, 2008). Selain itu, Ali dan Zhang (2015) menunjukkan bahwa manajer yang baru direkrut memiliki lebih banyak insentif untuk mengelola pendapatan daripada melaporkan kinerja yang baik dengan tujuannya dalam pembentukan reputasi. Pelaporan laba yang agresif membuat pemegang saham meragukan kredibilitas kinerja manajer yang dilaporkan sebelumnya dan merusak reputasi mereka. Hal ini menunjukkan bahwa manajer yang memiliki masa kerja lama memiliki lebih sedikit insentif untuk melaporkan pendapatan secara agresif. Selain itu, manajer dengan masa kerja yang lebih lama diharapkan lebih sadar akan potensi biaya hukum manajemen laba dan karenanya cenderung tidak terlibat di dalamnya. Berdasarkan penelitian-penelitian terdahulu maka hipotesis penelitian ini dinyatakan sebagai berikut; 
H2a: Masa jabatan rata-rata manajemen puncak berpengaruh negatif terhadap manajemen laba Akrual.

H2b: Masa jabatan rata-rata manajemen puncak berpengaruh negatif terhadap manajemen laba riil.

Peran Moderasi Kualitas Audit pada Pengaruh Pengetahuan Manajemen Puncak Terhadap Manajemen Laba

Dalam mengatasi konflik keagenan antara pemangku kepentingan dan manajemen teori agensi menjelaskan bahwa auditor dapat menjadi salah satu mekanisme pengawasan yang efektif. Laporan keuangan yang telah diaudit oleh auditor memiliki kredibilitas yang tinggi sehingga dapat digunakan untuk sarana pengambilan keputusan. Kualitas dari auditor mempengaruhi kaulitas jasa audit yang dihasilkan, semakin tinggi kualitas auditor maka semakin baik audit yang dihasilkan. DeAngelo (1981) dan Francis dan Yu (2009) meneliti tentang ukuran KAP terhadap kualitas audit, dalam hasil penelitiannya ditemukan bahwa KAP yang lebih besar menghasilkan audit yang lebih berkualitas. Maka pada penelitian ini KAP big-4 digunakan sebagai ukuran dari kualitas audit.

Menurut Hambrick dan Mason (1984) dalam penelitiannya tentang karakteristik pemimpin yang berkualitas, pemimpin yang memiliki tingkat pendidikan yang tinggi maka akan semakin komplek pengetahuan dan keterampilan serta pengalaman yang dimilikinya. Namun disisi lain pemimpin yang memiliki tingkat pendidikan yang lebih tinggi akan cenderung lambat dalam pengambilan keputusan, dikarenakan kemampuan kognitifnya yang lebih baik cenderung mendorong untuk mempertimbangkan banyak faktor termasuk resiko. Sedangkan tindakan memanajemen laba secara oportunistik dapat memberikan dampak yang sangat buruk baik bagi perusahaan dan reputasi mereka. Hal ini akan menjadi lebih beresiko jika dihadapkan dengan auditor yang mempunyai reputasi besar seperti KAP big-4.

Pada penelitian ini kualitas audit digunakan sebagai variabel yang memoderasi pengaruh pengetahuan manajemen puncak terhadap manajemen laba. Adanya auditor yang berkualitas diharapkan mampu untuk memperkuat akan pengetahuan maajemen puncak dan menekan perilaku manajemen laba yang dapat menyesatkan informasi para pemangku kepentingan. Maka hipotesis penelitian dinyatakan sebagai berikut;

\section{H3a: Kualitas Audit memperkuat pengaruh pengetahuan manajemen puncak yang berpengaruh negatif terhadap manajemen laba akrual.}

\section{H3b: Kualitas Audit memperkuat pengaruh pengetahuan manajemen puncak yang berpengaruh negatif terhadap manajemen laba riil.}

Peran Moderasi Kualitas Audit pada Pengaruh Masa Jabatan Rata-rata Manajemen Puncak Terhadap Manajemen Laba

Menurut Chemmanur et al. (2009) masa rata-rata jabatan manajemen puncak yang lebih lama memiliki kebijakan pengelolaan perusahaan lebih baik dan mengarah pada kinerja yang optimal. Perusahaan dengan kinerja yang lebih baik memiliki tingkat manajemen laba yang lebih rendah (Aier et al., 2005). Manajer yang memiliki masa jabatan yang lama cenderung akan mempertahankan posisinya dengan menjaga reputasi mereka, peran auditor yang berkualitas sebagai mekanisme pengawasan dianggap mampu untuk mengatasi konflik keagenan perusahaan. Dengan adanya auditor yang berkualitas diharapkan mampu untuk menekan para manajer untuk mengurangi perilaku mereka terhadap manajemen laba secara opurtunistik karena dapat mengancam reputasi yang sudah mereka bangun sejak lama. 
Penelitian ini menggunakan kualitas audit sebagai variabel moderasi pada pengaruh 139 masa jabatan rata-rata manajemen puncak terhadap manajemen laba, sehingga hipotesis penelitian dinyatakan sebagai berikut;

\section{H4a: Kualitas Audit memperkuat pengaruh masa rata-rata jabatan manajemen puncak yang berpengaruh negatif terhadap manajemen laba akrual.}

H4b: Kualitas Audit memperkuat pengaruh masa rata-rata jabatan manajemen puncak yang berpengaruh negatif terhadap manajemen laba riil.

\section{METODE}

Jenis penelitian ini adalah penelitian pengujian hipotesis (bypothesis testing), karena hipotesis dalam penelitian ini sudah ditentukan sejak awal riset dan bermaksud untuk memprediksi tentang suatu fenomena (Hartono, 2008). Populasi yang digunakan dalam penelitian ini adalah semua perusahaan manufaktur yang terdaftar di Bursa Efek Indonesia (BEI) pada periode pada periode 2014 sampai dengan 2018. Penelitian ini menggunakan perusahaan manufaktur sebagai populasi karena dalam penelitian ini menggunakan metode manajemen laba riil yang terkait dengan perhitungan biaya produksi serta adanya fenomena kebijakan pemerintah Indonesia yang dimana anggaran tersebut banyak disalurkan untuk pemerataan infrastrukur. Manipulasi produksi sebagai strategi manajemen laba hanya tersedia pada perusahaan-perusahaan manufaktur (Roychowdhury, 2006). Selanjutnya, pada penelitian ini sampel penelitian akan dipilih menggunakan teknik purposive sampling berdasarkan beberapa kriteria yang harus dipenuhi (judgement). Kriteria-kriteria perusahaan yang dijadikan sampel pada penelitian ini adalah sebagai berikut.

1. Perusahaan manufaktur yang terdaftar di Bursa Efek Indonesia selama tahun 2014 sampai dengan 2018 tanpa delisting.

2. Perusahaan mengungkapkan data lengkap yang dibutuhkan dalam penelitian ini seperti informasi yang dibutuhkan untuk menilai kualitas audit.

3. Perusahaan tidak mengalami kerugian selama periode 2014 sampai dengan 2018, karena penelitian ini mengukur tingkat akrual dari laba yang disajikan. Oleh karena itu apabila menggunakan perusahaan yang mengalami kerugian menjadi kurang tepat. Selain itu manajemen laba riil juga lebih cenderung digunakan untuk memperoleh laba, karena tidak mengharapkan sifat pembalikan seperti akrual.

\begin{tabular}{llc}
\hline No & \multicolumn{1}{c}{ Kriteria } & $\begin{array}{c}\text { Jumlah } \\
\text { Perusahaan }\end{array}$ \\
\hline 1 & Perusahaan manufaktur yang terdaftar di BEI 2014-2018 & 123 \\
2 & Data yang disajikan tidak lengkap & 36 \\
3 & Perusahaan mengalami kerugian & 45 \\
& Total & 42 \\
& Pengamatan selama 5 tahun (2014-2018) & $\mathbf{2 1 0}$
\end{tabular}

Tabel 1.

Sampel

Penelitian

Data dalam penelitian ini berasal dari data sekunder (secondary data) yaitu laporan keuangan tahunan perusahaan. Data sekunder adalah data yang telah ada dan tidak perlu JAA dikumpulkan oleh peneliti (Sekaran dan Bogie, 2017). Adapun sumber data keuangan dalam penelitian ini berasal dari situs resmi Bursa Efek Indonesia (www.idx.co.id) dan situs web 3.2 perusahaan. Data pasar diperoleh dari situs yahoo finance (http://finance.yahoo.com).

Penelitian ini menggunakan data panel yang terdiri dari cross section 42 perusahaan dan time series 5 tahun periode penelitian sehingga terdapat 210 observasi. Oleh karena itu, terdapat 
beberapa metode untuk menganalisis data panel berdasarkan tiga jenis model yaitu Pooled Ordinary Least Square, Fixed effects, dan Random effects yang dalam pemilihannya akan dilakukan uji chow, uji hausman, dan uji Lagrange multiplier untuk menentukan model terbaiknya.

\section{Definisi Operasional dan Pengukuran Variabel}

Variabel-variabel yang digunakan pada penelitian ini meliputi variabel independen yaitu pengetahuan manajemen puncak dan masa jabatan rata-rata manajemen puncak, variabel dependen yaitu manajemen laba, dan variabel moderasi yaitu kualitas audit. Definisi operasional dari masing-masing variabel adalah sebagai berikut.

\section{Variabel Dependen}

Variabel dependen dalam penelitian ini meliputi manajemen laba berdasarkan dua metode, yaitu manajemen laba berbasis akrual (accrual earnings management) dan manajemen laba riil (real earnings management). Definisi operasional masing-masing variabel independen dijelaskan sebagai berikut;

\section{Manajemen Laba Akrual}

Manajemen laba akrual adalah tindakan manajer dalam merekayasa laporan keuangan yang disajikan dengan memanfaatkan berbagai pilihan metode akuntansi yang ada dengan tujuan tertentu sehingga dapat menyesatkan para pemangku kepentingan. Proksi yang digunakan untuk mengukur manajemen laba akrual adalah akrual diskresioner (discretionary accrual). Penelitian ini menggunakan Model Modifikasi Jones Dechow et al. (1995) untuk menentukan akrual diskresioner karena model ini adalah model yang paling umum digunakan dalam penelitian.

Tahapan untuk menghitung manajemen laba akrual dengan model modifikasi Jones adalah sebagai berikut.

\section{Menghitung total akrual}

Total akrual diukur dengan persamaan berikut.

$\mathrm{TACC}_{\mathrm{i}, \mathrm{t}}=\mathrm{NI}_{\mathrm{i}, \mathrm{t}}-\mathrm{CFO}_{\mathrm{i}, \mathrm{t}}$

Nilai total akrual kemudian diestimasi menggunakan persamaan regresi OLS sebagai berikut.

$\frac{T A C C_{i, t}}{A_{i, t-1}}=\beta_{1}\left[\frac{1}{A_{i, t-1}}\right]+\beta_{2}\left[\frac{\Delta R E V_{i, t}-\Delta R E C_{i, t}}{A_{i, t-1}}\right]+\beta_{3}\left[\frac{P P E_{i, t}}{A_{i, t}}\right]+\varepsilon_{i, t}$

Koefisien yang diperoleh dari persaman regresi di atas digunakan untuk memperoleh nilai akrual non-diskesioner, dapat dihitung dengan rumus berikut.

$\frac{N D A C C_{i, t}}{A_{i, t-1}}=\beta_{1}\left[\frac{1}{A_{i, t-1}}\right]+\beta_{2}\left[\frac{\Delta R E V_{i, t}-\triangle R E C_{i, t}}{A_{i, t-1}}\right]+\beta_{3}\left[\frac{P P E_{i, t}}{A_{i, t}}\right]$

2. Akrual diskresioner merupakan selisih dari total akrual dengan akrual nondiskresioner. Akrual diskresioner dapat dihitung dengan rumus berikut.

$D A C C_{i, t}=\left[\frac{\operatorname{TACC}_{i, t}}{A_{i, t-1}}\right]-\left[\frac{N D A C C_{i, t}}{A_{i, t}-1}\right]$.

Keterangan:

TACC $_{\text {i.t }}$ : Total akrual perusahaan i pada tahun t.

NDACC $_{i, t}$ : Total akrual non-diskresioner perusahaan i pada tahun $\mathrm{t}$. 
DACC $_{i, t} \quad$ : Total akrual diskresioner perusahaan i pada tahun $\mathrm{t}$.

$\mathrm{NI}_{\mathrm{i}, \mathrm{t}} \quad$ : Laba bersih sebelum pos luar biaya perusahaan i pada tahun $\mathrm{t}$.

$\mathrm{CFO}_{\mathrm{i}, \mathrm{t}} \quad$ : Arus kas aktivitas operasi perusahaan i pada tahun $\mathrm{t}$.

$\triangle \mathrm{REV}_{\mathrm{i}, \mathrm{t}} \quad$ : Perubahan pendapatan perusahaan i pada tahun $\mathrm{t}$.

$\triangle$ REC : Perubahan piutang perusahaan i pada tahun $\mathrm{t}$.

$\mathrm{PPE}_{\mathrm{i}, \mathrm{t}} \quad$ : Aktiva tetap (Properti, plant, and equipment) perusahaan i tahun t.

$\mathrm{A}_{\mathrm{i}, \mathrm{t}-1} \quad$ : Total aset perusahaan i pada tahun $\mathrm{t}-1$

$\varepsilon_{\mathrm{i}, \mathrm{t}} \quad:$ Error

\section{Manajemen Laba Riil}

Manajemen laba riil (real earnings management) adalah suatu tindakan oportunistik yang dilakukan oleh manajemen puncak untuk memanipulasi angka laba pada laporan keuangan melalui aktivitas operasional nyata di perusahaan dan memiliki dampak langsung pada arus kas perusahaan. Roychowdhury (2006) membagi menjadi tiga ukuran manajemen laba riil yang dapat dilakukan oleh manajer, yaitu: arus kas operasi abnormal (ACFO), biaya produksi abnormal (APROD), dan biaya diskresioner abnormal (ADISEXP). Pengukuran masing-masing ukuran disajikan sebagai berikut.

\section{a. Arus Kas Operasi Abnormal (ACFO)}

Langkah-langkah untuk menghitung arus kas operasi adalah sebagai berikut (Roychowdhury, 2006).

1. Menghitung koefisien dari estimasi arus kas operasi normal menggunakan persamaan regresi berikut ini.

$\frac{C F O_{t}}{A_{t-1}}=\alpha_{0}+\alpha_{1}\left[\frac{1}{A_{t-1}}\right]+\beta_{1}\left[\frac{S_{t}}{A_{t-1}}\right]+\beta_{2}\left[\frac{\Delta S_{t}}{A_{t-1}}\right]+\varepsilon_{t}$

Koefisien yang diperoleh dimasukan kembali ke dalam persamaan regresi di atas untuk menghitung estimasi arus kas dari aktivitas operasi normal (CFO).

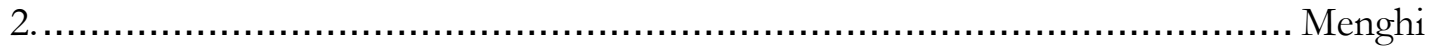

tung arus kas operasi abnormal (ACFO) adalah dengan cara mengurangkan antara nilai arus operasi aktual dengan nilai estimasi arus kas operasi yang diharapkan, untuk lebih jelasnya dapat dilihat pada persamaan berikut.

$A C F O=\frac{C F O_{t}}{A_{t-1}}-\left\{\alpha_{1}\left[\frac{1}{A_{t-1}}\right]+\beta_{1}\left[\frac{s_{t}}{A_{t-1}}\right]+\beta_{2}\left[\frac{\Delta s_{t}}{A_{t-1}}\right]\right\}$

Interpretasi dari arus kas operasi abnormal adalah semakin rendah arus kas operasi abnormal maka semakin tinggi perilaku manajemen laba riil yang dilakukan manajer.

\section{b. Biaya Produksi Abnormal (APROD)}

Langkah-langkah untuk menghitung biaya produksi abnormal adalah sebagai berikut (Roychowdhury, 2006).

JAA 1. Biaya produksi didefinisikan sebagai harga pokok penjualan (cost of goods sold) 3.2 ditambah dengan perubahan persediaan (Ainventory). Menghitung koefisien dari estimasi biaya produksi normal menggunakan persamaan regresi berikut. 


$$
\frac{P R O D_{t}}{A_{t-1}}=\alpha_{0}+\alpha_{1}\left[\frac{1}{A_{t-1}}\right]+\beta_{1}\left[\frac{S_{t}}{A_{t-1}}\right]+\beta_{2}\left[\frac{\Delta S_{t}}{A_{t-1}}\right]+\beta_{3}\left[\frac{\Delta S_{t-1}}{A_{t-1}}\right]+\varepsilon_{t}
$$

Koefisien yang diperoleh dimasukan kembali ke persamaan regresi di atas untuk menghitung estimasi biaya produksi normal.

tung biaya produksi abnormal (APROD) adalah dengan cara mengurangkan biaya produksi aktual dengan estimasi biaya produksi normal, seperti pada persamaan berikut.

$$
A P R O D=\frac{P R O D_{t}}{A_{t-1}}-\left\{\alpha_{1}\left[\frac{1}{A_{t-1}}\right]+\beta_{1}\left[\frac{s_{t}}{A_{t-1}}\right]+\beta_{2}\left[\frac{\Delta S_{t}}{A_{t-1}}\right]+\beta_{3}\left[\frac{\Delta S_{t-1}}{A_{t-1}}\right]\right\}
$$

Interpretasi dari biaya produksi abnormal adalah semakin tinggi biaya produksi abnormal maka manajemen laba riil semakin tinggi.

\section{c. Biaya Diskresioner Abnormal (ADISEXP)}

Langkah-langkah untuk menghitung biaya diskresioner abnormal adalah sebagai berikut (Roychowdhury, 2006).

1. Menghitung koefisien dari estimasi biaya diskresioner normal dengan menggunakan persamaan regresi berikut.

$$
\frac{D I S E X P_{t}}{A_{t-1}}=\alpha_{0}+\alpha_{1}\left[\frac{1}{A_{t-1}}\right]+\beta\left[\frac{s_{t}}{A_{t-1}}\right]+\varepsilon_{t}
$$

Koefisien yang diperoleh dimasukan kembali ke dalam persamaan di atas untuk menghitung estimasi biaya diskresioner normal (DISEXP).

2. Menghi tung biaya diskresioner abnormal (ADISEXP) dengan cara mengurangkan biaya diskresioner aktual dengan estimasi biaya diskresioner normal, untuk lebih jelasnya dapat dilihat pada persamaan berikut.

$$
\text { ADISEXP }=\frac{\text { DISEXP }_{t}}{A_{t-1}}-\left\{\alpha_{1}\left[\frac{1}{A_{t-1}}\right]+\beta\left[\frac{s_{t}}{A_{t-1}}\right]\right\}
$$

Interpretasi dari biaya diskresioner abnormal adalah semakin rendah biaya diskresioner abnormal maka semakin tinggi perilaku manajemen laba riil.

\section{d. Manajemen Laba Riil Gabungan}

Sebagai ukuran keseluruhan dari manajemen laba riil maka arus kas operasi abnormal (ACFO), biaya produksi abnormal (APROD), biaya diskresioner abnormal (ADISEXP) dijumlahkan. Mengikuti Cohen et al. (2008) manajemen laba riil dihitung sebagai berikut. ACFO dan ADISEXP dikalikan dengan -1 untuk menyamakan arah terhadap manajemen laba riil.

$\mathrm{REM}=\left(\mathrm{ACFO}^{*}-1\right)+\mathrm{APROD}+($ ADISEXP*-1)

Keterangan:

$\mathrm{CFO}_{\mathrm{t}} \quad$ : Arus kas operasi (cash flow from operation) perusahaan $\mathrm{i}$ tahun $\mathrm{t}$.

PROD $_{\mathrm{t}} \quad$ : Biaya produksi (production cost) perusahaan i tahun $\mathrm{t}$.

DISEXP $_{\mathrm{t}} \quad$ : Biaya diskresioner (discretionary expenses) perusahaan $\mathrm{i}$ tahun $\mathrm{t}$.

ACFO : Arus kas operasi abnormal (abnormal cash flow from operation). 
APROD : Biaya produksi abnormal (abnormal production cost).

ADISEXP : Biaya diskresioner abnormal (abnormal discretionary expenses).

REM : Ukuran gabungan manajemen laba riil.

$\mathrm{A}_{\mathrm{t}-1} \quad$ : Total aset perusahaan i pada tahun $\mathrm{t}-1$.

$\mathrm{S}_{\mathrm{t}} \quad$ : Total penjualan (sales) perusahaan i pada tahun $\mathrm{t}$.

$\Delta \mathrm{S}_{\mathrm{t}} \quad$ : Perubahan penjualan (sales) perusahaan i pada tahun t.

$\Delta \mathrm{S}_{\mathrm{t}-1} \quad$ : Perubahan penjualan (sales) perusahaan i pada tahun $\mathrm{t}-1$.

$\varepsilon_{\mathrm{t}} \quad:$ Error.

\section{Variabel Independen}

Penelitian ini mengangkat dua variabel independen yang akan diteliti. Variabel independen meliputi pengetahuan manajemen puncak dan masa jabatan rata-rata manajemen puncak, Definisi operasional masing-masing variabel independen dijelaskan sebagai berikut;

\section{Pengetahuan Manajemen Puncak}

Mengikuti penelitian sebelumnya Hsieh et al. (2018) dan Chemmanur et al. (2009) pengetahuan manajemen puncak dalam penelitian ini diproksikan dengan menggunakan prosentase dari jumlah anggota manajemen puncak dari tingkat pendidikan yang mereka miliki. Dengan kriteria yang dimiliki oleh anggota manajemen puncak yaitu tingkat pendidikan magister atau mempunyai gelar Certified Public Accountant (CPA). Selanjutnya untuk mendapatkan nilai prosentase pengetahuan anggota manajemen puncak dalam variabel ini menggunakan dummy, karena yang digunakan untuk mengkuantitatifkan variabel yang bersifat kualitatif (misal: jenis kelamin, pekerjaan, ras, tingkat pendidikan, agama dan lain-lain). Dummy dalam penelitian ini hanya mempunyai dua nilai, yaitu nilai 1 untuk anggota manajemen puncak yang memiliki gelar magister atau CPA dan nilai 0 untuk anggota manajemen puncak yang tidak memiliki gelar magister atau CPA.

\section{Masa Jabatan Rata-rata Manajemen Puncak}

Dalam menghitung variabel ini juga mengikuti penelitian sebelumnya (Hsieh et al., 2018) dan (Chemmanur et al., 2009), masa jabatan rata-rata manajemen puncak dihitung dari ratarata lama menjabat anggota manajemen puncak yang dapat dirumuskan sebagai berikut:

$$
\bar{X} T N R=\frac{\Sigma T N R}{\Sigma M T M}
$$

Keterangan:

X TNR : Rata-rata masa jabatan (tenure) manajemen puncak.

$\Sigma$ TNR : Total jumlah masa jabatan (tenure) anggota manajemen puncak.

$\Sigma$ MTM $\quad$ : Total anggota tim manajemen puncak (member top manajemen.

\section{Variabel Moderasi}

Variabel moderasi yang digunakan pada penelitian ini yaitu kualitas audit. Kualitas audit merupakan kemampuan auditor dalam menjaga kualitas laporan keuangan agar dapat

3.2 menyajikan informasi yang berguna dan kredibel bagi para penggunanya. Kualitas audit diukur menggunakan variabel dummy dari kualitas KAP, nilai 1 jika perusahaan di audit oleh KAP Big-4, dan 0 jika perusahaan diaudit oleh KAP nonbig-4. 


\section{Variabel Kontrol}

Variabel kontrol adalah suatu variabel yang melengkapi atau mengontrol hubungan kausalnya supaya lebih baik agar didapatkan model empiris yang lebih lengkap dan lebih baik. Dalam penelitian ini menggunakan usia dan jenis kelamin sebagai variabel kontrol. Penelitian ini menggunakan analisis regresi moderasi (Moderated Regression Analysis-MRA). Penggunaan metode MRA karena analisis ini dapat memberikan penjelasan yang lebih terperinci mengenai pengaruh antara variabel independen, variabel moderasi, dan variabel interaksi terhadap varibel dependen. Pengujian dilakukan menggunakan software eviews10.

Metode ini merupakan analisis regresi data panel secara bertahap. Tahap-tahap regresi data panel dengan MRA pada penelitian ini adalah sebagai berikut:

1. Menentukan analisis regresi pemodelan NDA untuk merumuskan nilai manajemen laba

2. Melakukan pemilihan model Pooled Ordinary Least Square, Fixed effects, dan Random effects. Uji Pengujian yang dapat dilakukan antara lain uji Chow untuk membandingkan antara model Pooled Ordinary Least Square dengan Fixed effects, uji Lagrange-Multiplier untuk membandingkan Pooled Ordinary Least Square dengan random effects dan uji Hausman untuk membandingkan Fixed effects dengan random effects.

3. Menganalisis model regresi 1 penelitian dengan memasukan variabel dependen dan variabel independen. Model regresi 1 digunakan untuk menguji Hipotesis 1 dan Hipotesis 2.

4. Menganalisis model regresi 2 penelitian dengan memasukan variabel dependen, variabel independen, variabel moderasi, dan interaksi antara variabel independen dengan variabel moderasi. Model regresi 2 digunakan untuk menguji Hipotesis 3 dan Hipotesis 4.

Berdasarkan empat tahapan MRA, maka empat model regresi dibangun pada penelitian ini sebagai berikut.

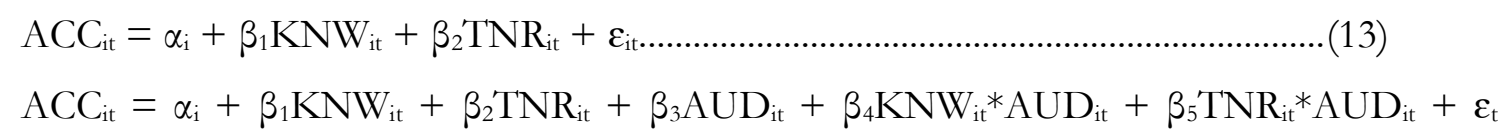

$\mathrm{REM}_{\mathrm{it}}=\alpha_{\mathrm{i}}+\beta_{1} \mathrm{KNW}_{\mathrm{it}}+\beta_{2} \mathrm{TNR}_{\mathrm{it}}+\varepsilon_{\mathrm{t}}$

$\mathrm{REM}_{\mathrm{it}}=\alpha_{\mathrm{i}}+\beta_{1} \mathrm{KNW}_{\mathrm{it}}+\beta_{2} \mathrm{TNR}_{\mathrm{it}}+\beta_{3} \mathrm{AUD}_{\mathrm{it}}+\beta_{4} \mathrm{KNW}_{\mathrm{it}} * \mathrm{AUD}_{\mathrm{it}}+\beta_{5} \mathrm{TNR}_{\mathrm{it}} * \mathrm{AUD}_{\mathrm{it}}+\varepsilon_{\mathrm{t}}$

Keterangan:

ACC : Akrual diskresioner perusahaan i pada tahun $\mathrm{t}$.

REM : Ukuran gabungan manajemen laba riil perusahaan i pada tahun $\mathrm{t}$.

KNW : Pengetahuan perusahaan i pada tahun t.

TNR : Rata-rata masa jabatan perusahaan i pada tahun t.

AUD $\quad$ : Kualitas audit (KAP big-4) perusahaan i pada tahun $t$

\section{HASIL DAN PEMBAHASAN}

Pengujian hipotesis dalam penelitian ini dilakukan dengan menggunakan model analisis regresi data panel dengan interaksi pada masing-masing variabel Pengetahuan, Lama menjabat, gender, usia, kualitas audit, Pengetahuan melalui kualitas audit dan Lama 
menjabat melalui kualitas audit terhadap manajemen laba akrual dan manajemen laba riil. Hasil uji pemilihan model data panel menunjukkan bahwa model common effect merupakan metode yang terpilih karena dinilai paling efektif berdasarkan uji chow, uji hausman, dan uji Lagrange multiplier. Uji hipotesis dilakukan melalui pengujian Godness of Fit yaitu uji koefisien determinasi, uji statistik $\mathrm{F}$ dan uji statistik t.

\begin{tabular}{|c|c|c|c|c|c|c|}
\hline \multirow{3}{*}{$\begin{array}{l}\text { No. } \\
1\end{array}$} & \multirow{3}{*}{$\begin{array}{c}\text { Metode } \\
\text { Chow Test }\end{array}$} & \multirow{3}{*}{\begin{tabular}{l}
\multicolumn{1}{c}{ Pengujian } \\
Common \\
Effect vs \\
Fixed Effect
\end{tabular}} & \multicolumn{4}{|c|}{ Hasil } \\
\hline & & & \multicolumn{2}{|c|}{ Accr. } & \multicolumn{2}{|c|}{ Riil } \\
\hline & & & 0.6384 & $\begin{array}{l}\text { Common } \\
\text { Effect }\end{array}$ & 0.9516 & $\begin{array}{l}\text { Common } \\
\text { Effect }\end{array}$ \\
\hline 2 & $\begin{array}{l}\text { Hausman } \\
\text { Test }\end{array}$ & $\begin{array}{l}\text { Fixed Effect } \\
\text { vs Random } \\
\text { Effect }\end{array}$ & 0.6553 & $\begin{array}{l}\text { Random } \\
\text { Effect }\end{array}$ & 0.9551 & $\begin{array}{l}\text { Random } \\
\text { Effect }\end{array}$ \\
\hline 3 & $\begin{array}{l}\text { Langrange } \\
\text { Multiplier } \\
\text { Test }\end{array}$ & $\begin{array}{l}\text { Common } \\
\text { Effect } \quad \text { vs } \\
\text { Random } \\
\text { Effect }\end{array}$ & 0.4000 & $\begin{array}{l}\text { Common } \\
\text { Effect }\end{array}$ & 0.1666 & $\begin{array}{l}\text { Common } \\
\text { Effect }\end{array}$ \\
\hline
\end{tabular}

Tabel 2. Hasil Perbandingan Pengujian Data Panel

Hasil pengujian model regresi data panel atas ketiga model data panel, tujuannya untuk memperkuat kesimpulan pengujian berpasangan, yang merekomendasikan penggunaan model Common Effect yang akan dianalisis lebih lanjut dalam penelitian ini.

\begin{tabular}{lcccccc}
\hline & \multicolumn{3}{c}{ Model 1 } & \multicolumn{3}{c}{ Model 2 } \\
& Coef. & $\mathbf{t}$ & Sig. & Coef. & $\mathbf{t}$ & Sig. \\
\hline (Constant) & 0,972 & 5,424 & 0,000 & 1,046 & 5,499 & 0,000 \\
Pengetahuan & $-0,140$ & $-2,573$ & 0,005 & 0,082 & 0,953 & 0,171 \\
Lama Menjabat & $-0,021$ & $-9,083$ & 0,000 & $-0,023$ & $-8,300$ & 0,000 \\
Proporsi Gender & $-0,390$ & $-3,351$ & 0,001 & $-0,496$ & $-3,936$ & 0,000 \\
Rata-Rata Usia & $-0,008$ & $-2,687$ & 0,004 & $-0,010$ & $-3,109$ & 0,001 \\
Kualitas Audit & & & & 0,061 & 0,806 & 0,261 \\
Pengetahuan_AUD & & & & $-0,349$ & $-3,086$ & 0,002 \\
Lama Menjabat_AUD & & & 0,003 & 0,552 & 0,291 \\
F-Value & 28,066 & & 0,000 & 18,198 & & 0,000 \\
Adjusted R & 0,341 & & & 0,365 & & \\
\hline
\end{tabular}

Tabel 3.

Hasil

Pengujian

Regresi Manajemen Laba Akrual

\begin{tabular}{lcccccc}
\hline & \multicolumn{3}{c}{ Model 1 } & \multicolumn{3}{c}{ Model 2 } \\
& Coef. & $\mathbf{t}$ & Sig. & Coef. & $\mathbf{t}$ & Sig. \\
\hline (Constant) & 0,514 & $-3,687$ & 0,000 & 0,543 & 3,724 & 0,000 \\
Pengetahuan & $-0,086$ & $-2,030$ & 0,022 & $-0,151$ & $-2,280$ & 0,012 \\
Lama Menjabat & $-0,005$ & $-2,507$ & 0,007 & $-0,008$ & $-3,833$ & 0,000 \\
Proporsi_Gender & $-0,497$ & $-5,476$ & 0,000 & $-0,532$ & $-5,509$ & 0,000 \\
Rata-rata_Usia & $-0,008$ & $-3,270$ & 0,001 & $-0,007$ & $-2,944$ & 0,001 \\
Kualitas Audit & & & & $-0,221$ & $-3,830$ & 0,000 \\
Pengetahuan_AUD & & & & 0,172 & 1,990 & 0,024 \\
Lama Menjabat_AUD & & & & 0,018 & 3,914 & 0,000 \\
F-Value & 10,452 & & 0,000 & 8,894 & & 0,000 \\
Adjusted R & 0,153 & & & 0,209 & & \\
\hline
\end{tabular}

Tabel 4.

Hasil

Pengujian

Regresi

Manajemen

Laba Riil 
Berdasarkan hasil pengujian regresi, maka diperoleh model regresi seperti berikut;

Model 1:

Manajemen laba akrual $=0,972-0,0140$ Pengetahuan $-0,021$ Lama menjabat -

Manajemen laba riil

0,3908 gender $-0,008$ usia $+\mu$

$=0,514-0,086$ Pengetahuan $-0,005$ Lama menjabat 0,497 gender $-0,008$ usia $+\mu$

Model 2:

Manajemen laba akrual $=1,046+0,082$ Pengetahuan $-0,023$ Lama menjabat 0,496 gender $-0,010$ usia $+0,061$ kualitas audit 0,349Pengetahuan*kualitas audit + 0,003Lama menjabat*kualitas audit $+\mu$

Manajemen laba riil

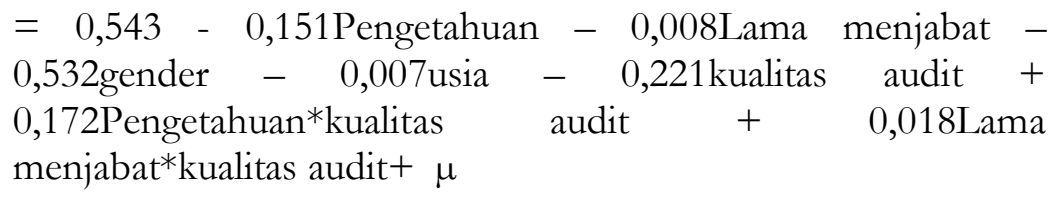

Hasil pengujian Hipotesis 1a model 1 variabel Pengetahuan diperoleh nilai koefisien negatif sebesar -0,140 dan memiliki t hitung sebesar -2,573 dengan tingkat signifikansi sebesar $0,005(<0,05)$. Artinya jika variabel Pengetahuan mengalami kenaikan sementara variabel independen lainnya diasumsikan tetap maka variabel manajemen laba akrual akan mengalami penurunan sebesar 0,140. Hipotesis 1a dalam penelitian ini yaitu "pengetahuan manajemen puncak berpengaruh negatif terhadap manajemen laba". Dengan demikian $\mathrm{H}_{\mathrm{a}}$ diterima, sehingga dapat dikatakan bahwa Pengetahuan berpengaruh negatif signifikan terhadap manajemen laba akrual.

Sedangkan hasil pengujian hipotesis $1 \mathrm{~b}$ pada model 1 diperoleh nilai koefisien regresi variabel Pengetahuan negatif sebesar -0,086 dan t hitung sebesar -2,030 dengan tingkat signifikansi sebesar 0,022 (<0,05), yang berarti jika variabel Pengetahuan mengalami kenaikan sementara variabel independen lainnya diasumsikan tetap maka variabel manajemen laba riil akan mengalami penurunan sebesar 0,086. Hipotesis $1 \mathrm{~b}$ dalam penelitian ini yaitu "pengetahuan manajemen puncak berpengaruh negatif terhadap manajemen laba". Dengan demikian $\mathrm{H}_{a}$ diterima, sehingga dapat dikatakan bahwa Pengetahuan berpengaruh negatif dan signifikan terhadap manajemen laba riil.

Hasil pengujian pada hipotesis 2a nilai koefisien regresi variabel Lama menjabat diperoleh nilai negatif sebesar -0,021 yang berarti jika variabel Lama menjabat mengalami kenaikan sementara variabel independen lainnya diasumsikan tetap maka variabel manajemen laba akrual akan mengalami penurunan sebesar 0,021. Dan pada hasil uji t variabel Lama menjabat memiliki t hitung sebesar -9,083 dengan tingkat signifikansi sebesar 0,000 $(<0,05)$. Hipotesis $2 \mathrm{a}$ dalam penelitian ini yaitu "Lama menjabat manajemen puncak berpengaruh negatif terhadap manajemen laba". Dengan demikian $\mathrm{H}_{\mathrm{a}}$ diterima, sehingga dapat dikatakan bahwa Lama menjabat berpengaruh negatif dan signifikan terhadap manajemen laba akrual.

Sedangkan hasil pengujian hipotesis $2 \mathrm{~b}$ nilai koefisien regresi variabel Lama menjabat diperoleh nilai negatif sebesar -0,005 dan memiliki t hitung sebesar -2,507 dengan tingkat signifikansi sebesar $0,007(<0,05)$, yang berarti jika variabel Lama menjabat mengalami kenaikan sementara variabel independen lainnya diasumsikan tetap maka variabel manajemen laba riil akan mengalami penurunan sebesar 0,005. Hipotesis $2 \mathrm{~b}$ dalam penelitian ini yaitu "Lama menjabat manajemen puncak berpengaruh negatif terhadap 
manajemen laba". Dengan demikian $\mathrm{H}_{\mathrm{a}}$ diterima, sehingga dapat dikatakan bahwa Lama menjabat berpengaruh negatif dan signifikan terhadap manajemen laba riil.

Sedangkan pada model 2 yaitu dengan memasukan variabel moderasi yang merupakan interaksi antara variabel Pengetahuan dan kualitas audit memiliki nilai koefisien negatif sebesar -0,349 t hitung sebesar -3,086 dengan tingkat signifikansi sebesar 0,002 $(<0,05)$, yang berarti jika variabel Pengetahuan mengalami kenaikan sementara variabel independen lainnya diasumsikan tetap maka variabel manajemen laba akrual akan mengalami penurunan sebesar 0,349. Hipotesis 3a dalam penelitian ini yaitu "Kualitas Audit memperkuat pengaruh pengetahuan manajemen puncak yang berpengaruh negatif terhadap manajemen laba". Dengan demikian $\mathrm{H}_{a}$ diterima, sehingga dapat dikatakan bahwa Pengetahuan berpengaruh negatif dan signifikan terhadap manajemen laba akrual dengan dimoderasi oleh variabel kualitas audit.

Dan pada hasil uji hipotesis $3 \mathrm{~b}$ model 2 diperoleh nilai koefisien regresi variabel Pengetahuan*kualitas audit diperoleh nilai positif sebesar 0,172 dan memiliki t hitung sebesar 1,990 dengan tingkat signifikansi sebesar 0,024 $(<0,05)$, yang berarti jika variabel Pengetahuan yang dimoderasi oleh variabel kualitas audit mengalami kenaikan sementara variabel independen lainnya diasumsikan tetap maka variabel manajemen laba riil akan mengalami peningkatan sebesar 0,172. Hipotesis $3 \mathrm{~b}$ dalam penelitian ini yaitu "Kualitas Audit memperkuat pengaruh pengetahuan manajemen puncak yang berpengaruh negatif terhadap manajemen laba". Dengan demikian $\mathrm{H}_{\mathrm{a}}$ ditolak, sehingga dapat dikatakan bahwa Pengetahuan berpengaruh positif signifikan terhadap manajemen laba riil dengan dimoderasi oleh variabel kualitas audit.

Hasil uji hipotesis 4 a model 2 diperoleh nilai koefisien regresi variabel Lama menjabat*kualitas audit diperoleh nilai positif sebesar 0,003 dengan nilai t hitung sebesar 0,552 dengan tingkat signifikansi sebesar 0,291 $(>0,05)$, yang berarti jika variabel Lama menjabat mengalami kenaikan sementara variabel independen lainnya diasumsikan tetap maka variabel manajemen laba akrual akan mengalami peningkatan sebesar 0,003. Dan pada hasil uji $\mathrm{t}$ menunjukan. Hipotesis 4a dalam penelitian ini yaitu "Kualitas Audit memperkuat pengaruh Lama menjabat manajemen puncak yang berpengaruh negatif terhadap manajemen laba". Dengan demikian $\mathrm{H}_{\mathrm{a}}$ ditolak, sehingga dapat dikatakan bahwa Lama menjabat berpengaruh positif dan tidak signifikan terhadap manajemen laba akrual dengan dimoderasi oleh variabel kualitas audit.

Sedangkan hasil uji hipotesis 4b yang merupakan interaksi antara variabel Lama menjabat dan kualitas audit diperoleh nilai koefisien nilai positif sebesar 0,018 dan t hitung sebesar 3,914 dengan tingkat signifikansi sebesar $0,000(<0,05)$, yang berarti jika variabel Lama menjabat yang dimoderasi oleh variabel kualitas audit mengalami kenaikan sementara variabel independen lainnya diasumsikan tetap maka variabel manajemen laba riil akan mengalami kenaikan sebesar 0,019. Hipotesis 4b dalam penelitian ini yaitu "Kualitas Audit memperkuat pengaruh Lama menjabat manajemen puncak yang berpengaruh negatif terhadap manajemen laba". Dengan demikian $\mathrm{H}_{a}$ ditolak, sehingga dapat dikatakan bahwa Lama menjabat berpengaruh positif dan signifikan terhadap manajemen laba riil dengan dimoderasi oleh variabel kualitas audit.

JAA Uji asumsi klasik meliputi uji normalitas, autokorelasi, multikolinieritas, dan heteroskedastisitas. Dari pengujian secara statistik diperoleh data residual pada penelitian ini 3.2 terdistribusi secara normal. Model regresi juga menunjukkan bahwa tidak terjadi autokorelasi, multikolinearitas antar variabel bebas dalam model regresi dimana nilai VIF $<$ 
10. Selain itu, secara statistik model regresi pada penelitian ini tidak mengandung adanya heteroskedastisitas.

Uji koefisien determinasi $\left(\mathrm{R}^{2}\right)$ dilakukan untuk mengukur kemampuan variabel independen dalam menerangkan variasi variabel dependen dan menunjukkan hasil bahwa nilai adjusted $\mathrm{R}^{2}$ pada model regresi 1 manajemen laba akrual sebesar 0,341 . Hal ini mendandakan bahwa variasi variabel Pengetahuan, Lama menjabat, gender dan usia dapat menjelaskan 34,1\% variasi variabel manajemen laba akrual. Sedangkan sisanya, sebesar 65,9\% dijelaskan oleh variabel lain diluar penelitian ini. Sedangkan pada model regresi 2 manajemen laba akrual sebesar 0,365 Hal ini mendandakan bahwa variasi variabel Pengetahuan, Lama menjabat, gender, usia, kualitas audit, Pengetahuan*kualitas audit dan Lama menjabat*kualitas audit dapat menjelaskan 36,5\% variasi variabel manajemen laba akrual. Sedangkan sisanya, sebesar $63,5 \%$ dijelaskan oleh variabel lain diluar penelitian ini.

Selanjutnya hasil uji koefisian korelasi dan determinasi menunjukan bahwa nilai adjusted $\mathrm{R}^{2}$ pada model regresi 1 manajemen laba riil sebesar 0,153. Hal ini mendandakan bahwa variasi variabel Pengetahuan, Lama menjabat, gender dan usia dapat menjelaskan 15,3\% variasi variabel manajemen laba riil. Sedangkan sisanya, sebesar $84,7 \%$ dijelaskan oleh variabel lain diluar penelitian ini. Sedangkan pada model regresi 2 manajemen laba riil sebesar 0,209. Hal ini mendandakan bahwa variasi variabel Pengetahuan, Lama menjabat, gender, usia, kualitas audit, Pengetahuan*kualitas audit dan Lama menjabat*kualitas audit dapat menjelaskan $20,9 \%$ variasi variabel manajemen laba riil. Sedangkan sisanya, sebesar 79,1\% dijelaskan oleh variabel lain diluar penelitian ini.

Model penelitian harus diuji apakah model regresi penelitian layak digunakan atau tidak dalam penelitian yang dilakukan, sehingga perlu dilakukan uji F. Regresi model 1 manajemen laba akrual menunjukkan nilai F-Value sebesar 28,066 dengan signifikansi hasil uji F sebesar 0,000 kurang dari 0,05 sehingga dapat disimpulkan bahwa variabel Pengetahuan, Lama menjabat, gender dan usia berpengaruh secara simultan terhadap variabel dependen yaitu manajemen laba akrual. Dan pada regresi model 2 manajemen laba akrual menunjukkan nilai F-Value sebesar 18,198 dan signifikansi hasil uji F sebesar 0,000 kurang dari 0,05 sehingga dapat disimpulkan bahwa variabel Pengetahuan, Lama menjabat, gender, usia, kualitas audit, Pengetahuan*kualitas audit dan Lama menjabat*kualitas audit berpengaruh secara simultan terhadap variabel dependen yaitu manajemen laba akrual.

Sedangkan pada regresi model 1 manajemen laba riil menunjukkan nilai F-Value sebesar 10,452 dengan signifikansi uji $\mathrm{F}$ sebesar 0,000 kurang dari 0,05 sehingga dapat disimpulkan bahwa variabel Pengetahuan, Lama menjabat, gender dan usia berpengaruh secara simultan terhadap variabel dependen yaitu manajemen laba riil. Dan pada regresi model 2 manajemen laba riil menunjukan nilai F-Value sebesar 8,894 dengan signifikansi sebesar 0,000 kurang dari 0,05 sehingga dapat disimpulkan bahwa variabel Pengetahuan, Lama menjabat, gender, usia, kualitas audit, Pengetahuan*kualitas audit dan Lama menjabat*kualitas audit berpengaruh secara simultan terhadap variabel dependen yaitu manajemen laba riil.

\section{Pembahasan}

Pendidikan dapat mengembangkan potensi seseorang, sehingga dapat mewujudkan kepribadian, kecerdasan serta keterampilan yang diperlukan. Semakin tinggi pendidikan maka akan semakin kompleks pengetahuan yang mereka miliki. Dengan pengetahuan yang tinggi yang dimiliki oleh manajemen puncak maka seharusnya manajemen puncak dapat lebih bijak dalam pengambilan kebijakan keuangan perusahaan. Tindakan manajemen laba yang ekstrim memiliki resiko yang tinggi dalam keberlangsungan kesehatan perusahaan.

JAA 3.2 
Maka dari itu pengetahuan dapat meminimalisir tindakan manajemen dalam melakukan manajemen laba yang dilakukan perusahaan.

Hasil pengujian menunjukan bahwa pengetahuan yang diproksikan dengan tingkat pendidikan berpengaruh negatif terhadap manajemen laba akrual dan riil dan hasil penelitian ini mendukung Hipotesis 1a dan 1b. Maka dengan ini memberikan bukti bahwa karakterikstik manajemen puncak yang memiliki tingkat pendidikan yang tinggi dapat mengurangi tindakan manajemen laba akrual maupun riil. Hasil penelitian ini sejalan dengan temuan penelitian Annisa (2013), Xiong (2016) dan Qi et al. (2018) yang menemukan bahwa tingkat pendidikan berpengaruh negatif terhadap manajemen laba. Disisi lain hasil penelitian ini berbeda dengan temuan Finkelstein (1992) yang menemukan bahwa tingkat pendidikan berpengaruh positif terhadap manajemen laba. Hasil ini mendukung teori upper echelon bahwa manajemen puncak yang memiliki pengetahuan yang tinggi akan bekerja lebih baik dan kebijakannya banyak melakukan pertimbangan banyak faktor yang dapat mempengaruhii kesehatan perusahaan. Kebijakan yang dirasa dapat mengancam keberlangsungan perusahaan akan diminimalisir agar terhindar dari resiko yang besar.

Manajemen puncak yang sudah lama menjabat cenderung akan mempertahankan posisi mereka dalam kedudukannya. Karena dengan memiliki jabatan yang tinggi dan sudah lama menjabat mereka memiliki pengaruh yang besar dalam kebijakan yang akan diambil oleh perusahaan. Hasil pengujian regresi menunjukan bahwa manajemen puncak yang memiliki masa jabatan yang tinggi dapat mengurangi praktik manajemen laba. Maka dengan ini hipotesis $2 \mathrm{a}$ dan $2 \mathrm{~b}$ terbukti bahwa masa jabatan yang tinggi memiliki pengaruh negative terhadap manajemen laba. Hasil ini sejalan dengan penelitian yang dilakukan oleh Xiong (2016) yang menemukan bahwa masa jabatan yang tinggi dapat mengurangi praktik manajemen laba. Hasil ini mendukung teori upper echelon yang menyatakan bahwa masa jabatan yang menunjukan lama waktu seseorang dalam menduduki jabatannya sebagai pemimpin sebuah organisasi cenderung akan mempertahankan posisinya.

Kualitas audit perusahaan dalam penelitian ini diproksikan dengan perusahaan yang menggunakan jasa KAP BIG-4, kualitas auditor yang dimiliki KAP BIG-4 mempunyai kemampuan yang sangat baik dalam akutansi. Auditor yang berkualitas dirasa mampu dalam melakukan mekanisme kontrol bagi pihak-pihak yang berkepentingan di sebuah organisasi. Oleh sebab itu, auditor yang berkualitas diharapkan mampu dalam membatasi praktik manajemen laba terhadap kebijakan yang dilakukan perusahaan. Hasil pegujian kualitas audit yang memperkuat pengaruhnya pengetahuan terhadap manajemen laba memiliki dua hasil yang berbeda. Dalam pengaruhnya pengetahuan terhadap manajemen laba akrual kualitas audit dapat memperkuat pengaruhnya, hal ini sejalan dalam penelitian Rusmin (2010) dan Alzoubi (2016) yang menemukan bahwa perusahaan yang diaudit oleh KAP BIG-4 dapat mengurangi manajemen laba. Sedangkan dalam praktik manajamen laba riil, temuan penelitian ini kualitas audit dapat meningkatkan praktik manajemen laba riil. Hal ini sejalan dengan temuan penelitian yang dilakukan oleh Challen dan Siregar (2012), yang dalam penelitiannya menemukan bahwa perusahaan yang diaudit oleh auditor spesialis dapat memperkuat manajemen laba riil karena tindakan majamen laba akrual lebih mudah ditemukan oleh auditor.

Hasil pengujian regresi kualitas audit yang memperkuat pengaruh masa jabatan puncak dalam menurunkan manajemen laba tidak terbukti. Dalam pengaruhnya terhadap

JAA manajemen laba akrual kualitas audit tidak terbukti memperkuat pengaruhnya masa jabatan terhadap tindakan manajemen puncak dalam melakukan praktik manajemen laba, 3.2 sedangkan dalam manajamen laba riil kualitas audit terbukti memperkuat pengaruhnya dalam tindakan atau praktik manajemen laba riil. Hasil pengujian ini membuktikan bahwa self interest dalam teori agensi yang dinyatakan oleh Eisenhardt (1989) bahwa tindakan yang 
dilakukan manajemen bersifat mementingkan kepentingan pribadinya. Karena asumsi itulah manjemen puncak akan mementingkan utiltasnya terlebih dahulu, sehingga manjemen puncak cenderung bertindak opurtunistik. Hasil penelitian ini juga mendukung penelitian yang dilakukan oleh Challen dan Siregar (2012). Dengan asumsi manajemen puncak yang memiliki masa jabatan yang tinggi mereka cenderung bertindak dalam memepertahankan posisi mereka, dikarenakan tindakan manajemen laba akrual yang lebih mudah dideteksi oleh para auditor tindakan manajemen laba riil adalah salah satu pilihan yang mereka lakukan agar dapat mempertahankan posisi yang mereka jabat.

\section{SIMPULAN}

Pada model 1 pengetahuan dan lama menjabat manajemen puncak memiliki pengaruh negatif terhadap manajemen laba akrual maupun riil. Hal ini sejalan dengan teori upper echelon yang menyatakan bahwa manajemen puncak yang memiliki pengetahuan yang tinggi dan memiliki masa jabatan yang lama akan bekerja lebih baik dan kebijakannya banyak melakukan pertimbangan banyak faktor yang dapat mempengaruhii kesehatan perusahaan. Kebijakan yang dirasa dapat mengancam keberlangsungan perusahaan akan diminimalisir agar terhindar dari resiko yang besar. Sedangkan pada model 2 pengetahuan yang dimoderasi oleh kualitas audit memiliki pengaruh negatif terhadap manajemen laba akrual, sedangkan pada manajemen laba riil memiliki pengaruh positif. Dan pada lama menjabat tidak memiliki pengaruh terhadap manajemen laba akrual, sedangkan pada pengaruhnya manajemen riil lama menjabat memiliki pengaruh positif. Hasil pada model 2 memperkuat teori agensi dari (Eisenhardt, 1989) yang membuktikan manajemen bersifat mementingkan kepentingan pribadinya, karena dengan tindakan manajemen laba riil adalah salah satu tindakan yang sulit untuk dideteksi oleh audit.

Keterbatasan dalam penelitian ini Peneliti masih sulit untuk dapat menemukan komponen biaya Research and Development (R\&D) dalam satu akun untuk mengukur biaya diskresioner abnormal pada manajemen laba riil, sehingga peneliti hanya memasukan total biaya penjualan dan total biaya administrasi dan umum sebagai ukuran biaya diskresioner. Penelitian ini juga hanya mengambil sampel dari perusahaan manufaktur. Saran untuk penelitian selanjutnya agar dapat lebih mengeksplorasi data perusahaan untuk memperoleh komponen biaya R\&D secara lebih spesifik dengan melakukan penelurusan secara langsung ke perusahaan sampel dan melakukan penelitian yang lebih luas yang tidak hanya mengambil sampel dari perusahaan manufaktur atau dapat menambahkan perusahaan jasa sebagai sampel penelitian.

\section{DAFTAR PUSTAKA}

Aier, J. K., J. Comprix, M. T. Gunlock, dan D. Lee. 2005. "The Financial Expertise of CFOs and Accounting Restatements". Accounting Horizons, Vol. 19, No. 3, hlm: 13.

Ali, A., dan W. Zhang. 2015. "CEO tenure and earnings management". Journal of Accounting and Economics, Vol. 59, No. 1, hlm: 20.

Alzoubi, E. S. S. 2016. "Audit quality and earnings management: evidence from Jordan". Journal of Applied Accounting Research, Vol. 17, No. 2, hlm: 19.

Annisa. 2013. "Pengaruh Latar Belakang Pendidikan Dewan Komisaris, Kepemilikan Institusional Dan Ukuran Perusahaan Terhadap Integritas Laporan Keuangan (Studi Empiris pada Perusahaan Manufaktur yang terdaftar di BEI)". Jurnal Akuntansi, Vol. 1, No. 8, hlm: 26. 
Challen, A. E., dan S. V. Siregar. 2012. "Audit Quality On Earnings Management And Firm Value". Journal Perbanas, Vol. 14, No. 4, hlm: 14.

Chemmanur, T. J., dan I. Paeglis. 2005. "Management quality,certification, and initial public offerings". Journal of Financial Economics Vol. 76, No. 2, hlm: 38.

Chemmanur, T. J., I. Paeglis, dan K. Simonyan. 2009. "Management Quality, Financial and Investment Policies, and Asymmetric Information". Journal of Financial and Quantitative Analysis, Vol. 44, No. 5, hlm: 35.

Chou, Y.-Y., dan M.-L. Chan. 2018. "The Impact of CEO Characteristics on Real Earnings Management: Evidence from the US Banking Industry". Journal of Applied Finance \& Banking, Vol. 8, No., hlm: 28.

Cohen, D. A., A. Deyb, dan T. Z. Lysc. 2008. "Real and Accrual-Based Earnings Management in the Pre- and Post-Sarbanes-Oxley Periods". The Accounting Review, Vol. 83, No. 3, hlm: 30.

DeAngelo, L. E. 1981. "Auditor size and audit quality". Journal of Accounting and Economics Vol. 3, No. 3, hlm: 17.

Dechow, P. M., R. G. Sloan, dan A. P. Sweeney. 1995. "Detecting Earnings Management ". The Accounting Review Vol. 70, No. 2, hlm: 34.

Demerjian, P. R., B. Lev, M. F. Lewis, dan S. E. McVay. 2013. "Managerial Ability and Earnings Quality". The Accounting Review, Vol. 88, No. 2, hlm: 36.

Dowd, K. 2016. "A Comparison of Accounting Fraud Before and After Sarbanes-Oxley". Vol. 1, No., hlm: 30.

Eisenhardt, K. M. 1989. "Agency Theory: An Assessment and Review". Journal Academy Of Management, Vol. 14, No. 1, hlm: 19.

FASB. 1978. "Objectives of Financial Reporting by Business Enterprises". Vol. Concepts Statement No. 1, No. 11, hlm.

Finkelstein, S. 1992. "Power in Top Management Teams: Dimensions, Measurement, and Validation". Journal Academy Of Management, Vol. 35, No. 3, hlm: 35.

Francis, J. R., dan M. D. Yu. 2009. "Big 4 Office Size and Audit Quality". The Accounting Review, Vol. 9, No. 5, hlm: 32.

Haleblian, J., dan S. Finkelstein. 1993. "Top Management Team Size, Ceo Dominance, And Eirm Pereormance: The Moderating Roles Of Environmental Turbulence And Discretion". Academy Of Management Journal, Vol. 36, No. 4, hlm: 21.

Hambrick, D. C., dan R. A. D'Aveni. 1992. "Top Team Deterioration as Part of the Downward Spiral of Large Corporate Bankruptcies". Management Science, Vol. 38, No. 10, hlm: 23.

Hambrick, D. C., dan P. A. Mason. 1984. "Upper Echelons: The Organization as a Reflection of Its Top Managers". Accademy of Management Review, Vol. 9, No. 2, hlm: 14.

JAA

Hartono, J. 2008. "Teori portofolio dan analisis investasi". Yogyakarta: BPFE, Vol., No., 3.2 hlm. 
Herawaty, V. 2008. "Peran Praktek Corporate Governance Sebagai Moderating Variable dari Pengaruh Earnings Management Terhadap Nilai Perusahaan". Jurnal Akuntansi dan Keuangan, Vol. 10, No. 2, hlm: 11.

Hsieh, Y.-T., T.-K. Chenb, Y.-J. Tsengc, dan R.-C. Linc. 2018. "Top Management Team Characteristics and Accrual-Based Earnings Management". International Journal of Accounting, Vol. 53, No. 4, hlm: 21.

Huovinen, S., dan M. Pasanen. 2010. "Entrepreneurial and management teams: What makes the difference?". Journal of Management \& Organization, Vol. 16, No. 3, hlm: 19.

Johan, A. P., dan A. Wibowo. 2012. "Diversitas Tim Manajemen Puncak, Kekomprehensifan Pengambilan Keputusan, Integrasi Sosial Dan Kinerja Perusahaan: Studi Pada Bank Perkreditan Rakyat". Jurnal Siasat Bisnis, Vol. 16, No. 2, hlm: 12 .

Khanh, H. T. M., dan N. V. Khuong. 2018. "Audit Quality, Firm Characteristics and Real Earnings Management: The Case of Listed Vietnamese Firms". International Journal of Economics and Financial Issues, Vol. 8, No. 4, hlm: 7.

Li, C.-R. 2014. "Top management team diversity in fostering organizational ambidexterity: Examining TMT integration mechanisms". Innovation Management, Policy \& Practice, Vol. 16, No. 3, hlm: 21.

Li, Y. 2010. "The Case Analysis of the Scandal of Enron". International Journal of Business and Management Vol. 5, No. 3, hlm: 5.

Matsunaga, S. R., dan P. E. Yeung. 2008. "Evidence on the Impact of a CEO's Financial Experience on Quality of the Firm's Financial Reports and Disclosures ". SSRN Electronic Journal, Vol., No., hlm.

Michel, J. G., dan D. C. Hambrick. 1992. "Diversification Posture and Top Management Team Characteristics". The Academy of Management Journal, Vol. 35, No. 1, hlm: 29.

Qi, B., J. W. Lin, G. Tian, dan H. C. X. Lewis. 2018. "The Impact of Top Management Team Characteristics on the Choice of Earnings Management Strategies: Evidence from China". American Accounting Association, Vol. 34, No. 1, hlm: 22.

Roychowdhury, S. 2006. "Earnings management through real activities manipulation". Journal of Accounting and Economics, Vol. 42, No. 3, hlm: 36.

Rusmin. 2010. "Auditor quality and earnings management: Singaporean evidence". Managerial Auditing Journal, Vol. 25, No. 7, hlm: 21.

Scott, W. R. 2015. "Financial Accounting Theory, 7th Edition". Vol., No., hlm.

Sekaran, U., dan R. Bogie. 2017. "Metode Penelitian untuk Bisnis". Vol. 6, No., hlm.

Sidak, J. G. 2003. "The Failure of Good Intentions: The WorldCom Fraud and the Collapse of American Telecommunications After Deregulation ". SSRN Electronic Journal, Vol. 20, No. 2, hlm: 61.

Watts, R. L., dan J. L. Zimmerman. 1990. "Positive Accounting Theory: A Ten Year Perspective". The Accounting Review, Vol. 65, No. 1, hlm: 26.

Xiong, J. 2016. "Chairman Characteristics and Earnings Management: Evidence from Chinese Listed Firms". Open Journal of Accounting, Vol. 5, No. 4, hlm: 13. 